\title{
Sukuk sebagai Instrument Pendanaan Negara
}

\author{
Oleh: Sofyan Syafri Harahap*
}

\begin{abstract}
The financial and economic crisis in America has affected emerging market (such as Indonesia). Indonesia now is lacking liquidity funds to finance its economic development. US Federal Government has bailed out and helped most multinational corporations to avoid bankruptcy and to stimlat economic growth. To fulfill the need for development financing, Indonesia may consider Islamic products financing that has been known in International financial market such as SUKUK. Fortunately, Indonesia has ratified SUKUK Act therefore, Indonesia may issue an Islamic financial scheme. The funds owned by a number of Middle Eeast investors as well as western investors have invested in Islamic scheme finance. So SUKUK can be another alternative that can be offered by Indonesian government as a source of public funds to finance economic development.
\end{abstract}

Keywords: Sukuk, Islamic Finance, SBSN, Public Finance.

\section{Pendahuluan}

Dengan munculnya krisis keuangan Global maka mau tidak mau Indonesia ketiban sialnya. Likuditas yang selama ini bisa dinikmati untuk membangun ekonomi bangsa kembali pulang kampung keasalnya dan kembali diinvestasikan di negara negara yang lagi mengalami kebutuhan likuiditas yaitu Amerika dan Eropa. Akibat Krisis beberapa perusahaan harus bangkrut dan sebahagian masih bisa diselamatkan oleh pemerintahnya. Dana stimulus atau dana bail out terpaksa dikucurkan pemerintahnya untuk mengamankan sistem keuangan dan stabilitas ekonomi politik negaranya.Akibat krisis global yang menurut beberapa analisis adalah karena sistem kapitalisme yang tidak bsia menahan keserakahan dan untuk memenuhinya harus ditutupi dengan utang dan produk produk hutang lainnya seperti derivatif, maka muncul ketidak percayaan terhadap sistem kapitalisme. Dengan munculnya sistem ekonomi keuangan Islam dan produk produknya seperti SUKUK atau Obligasi syariah maka muncul fajar baru yang akan menjadi kompetitor kuat dari produk produk keuangan kapitalisme. Tulisan ini

*Penulis adalah Ketua Program Pasca Sarjana Program Studi Ekonomi Islam Trisakti Jakarta. Email: sofyansyafri@yahoo.com 
mencoba membahas potensi SUKUK sebagai salah satu instrument pembiayaan pembangunan negara khusunya bangsa kita.

\section{Likuiditas dan Sumbernya}

Setelah krisis global melanda dunia yang dimulai dri Amerika maka muncul tiga fenomena: Pertama: Negara yang selama in menjadi sumber keuangan Negara dan korporasi mengalami kekurangan likuiditas akibatnya negara berkembang mengalami krisis likuiditas karena likuiditas yang selama ini berada di negaranya terhisap oleh kebutuhan di negara yang baru terkena krisis seperti Amerika dan Eropa. Kedua: Sumber likuiditas selama juga banyak disupply oleh para eksportir minyak yang menuikmati "petro dollar" akibat kenaikan beberapa kali harga minyak. Sebahagian besar dana itu berada di kantong kantong negara Timut Tengah atau yang memiliki keyakinan Islam. Ketiga: Dampak lain dari krisis global itu adalah keyakinan bahwa sudah muncul era akhr kapitalisme yang selama ini didengung dengungkan kehebatannya bahkan oleh Francis Fukuyama (1989) dinilai sebagai "the end of history", sebagai prestasi puncak peradaban manusia yang tidak akan ada lagi prestasi diatasnya. Namun ternyata hancur ditelan sistemnya sendiri ${ }^{1}$.

Bagi Indonesia yang mayoritas Islam ketiga fenomena ini harus diantisipasi untuk kebutuhan pembangunan nasional. Kekeringan likuiditas yang kita alami akan berdampak pada pertumbuhan ekonomi yang pada akhirnya akan berdampak pada semakin jauhnya upaya untuk mensejahterakan rakyat Indonesia yang masih bergumul dengan semakin banyaknya rakyat yang berada dalam kemiskinan ${ }^{2}$. Kurangnya likuditas ini sudah mulai terasa. Sehingga dalam Indonesian Paper yang dibawa Menteri Keuangan ke Sao Paulo, Brazil suatu pertemuan para Menteri Keuangan G-20 mendahului pertemuan Pemimpin Dunia G-20 di Washington pada tanggal 15-16 November 2008 mengusulkan agar IMF dan Bank Dunia menyiapkan dana untuk dipinjamkan ke negara negara emerging market yang akan mengalami kesulitan likuiditas ${ }^{3}$. Disini tampak sekali Pemerintah Indonesia, minimal Menteri Keuangan menunjukkan mazhab model pembangunannya adalah mazhab IMF yang selama ini mengandalkan Hutang sebagai cara membangun negerinya ${ }^{4}$. Apakah Indonesia yang masuk dalam

${ }^{1}$ Sofyan S Harahap (2008), "Ekonomi Syariah Yang Sabar Menunggu”, Republika, 29 September 2008.

${ }^{2}$ Raja Hendrik Napitupulu (2008), "2009 jumlah orang miskin jadi 43 Juta jiwa, Penduduk miskin melonjak", Investor Daily, Senin 24 November, 2008 hal 1.

${ }^{3}$ LeVine, Steve (2008), The IMF is Back, Kinder and Gentler, Business Week, November 10, 2008.

${ }^{4}$ Sofyan S Harahap (2008), "Ekonomi Syriah Yang Sabar Menunggu", Republika, 29 September 2008. 
perangkap IMF pada krisis Asia 1997 dan samapi saat ini kita belum bisa keluar sepenuhnya masih dipakai lagi? Apakah kita yang oleh DPR dan Pemerintah sudah keluar dari IMF masih akan ulangi lagi?

\section{Potensi Pasar Keuangan Islam}

Sebenarnya dana likuiditas yang selama ini ada berada ditangan China, Jepang dan negara negara Timur Tengah sebagai penikmat "petro dollar" akibat kenaikan harga minyak yang spketakuler pada beberapa bulan yang lalu. China dan Jepang sebenarnya sukar diharap karena kemungkinan besar dana itu akan mengalir ke Amerika sebagai negara pengimpor terbesar barang barang produksi China dan Jepang. Wajar jika surplus mereka ini masuk kembali ke Amerika sekaligus untuk menyelematkan pasar mereka. Sehingga sebenarya dana likuiditas yang lebih "merdeka" adalah dana Timur Tengah. Karena Timur Tengah ini sudah mulai menyadari bahaya kapitalisme dan mulai tumbuh keyakinan agamanya maka oleh karena itu skim pembiayaan atau sasaran investasinya adalah investasiyang lebih ama dan sesuai dengan keimanannya yaitu produk berbasis syariah.

Menurut Balfour (2008) dana dana yang ditanamkan di mutual fund konvensional sudah mulai menurun dan masuk ke dana Islamic Mutual fund. Produk Islami mutual fund ini memang iktu juga jatuh akibat krisis keuangan global tetapi jauh lebih rendah. Jika skim konvensional jatuh $41 \%$ Islamic mutual fund hanya jatuh berkisar 30\%. Ini berarti skim syariah sudah mulai diterima pasar dan bukan saja oleh orang muslim akan tetapi juga oleh non-muslim. Menurut Balfour (2008) 2/3 dari dana yang diinvestasikan dalam Islamic mutual fund justru berasal dari non muslim. Menurut Umer Chapra (Ghafour, 2008) dalam situasi krisis saat ini terbukti bahwa sistem keuangan Islam merupakan jalan keluar dari krisis global yang dihadapi dunia saat ini.

\section{Kinerja, Potensi dan Kendala Sukuk}

Sukuk pada hakikatnya adalah surat berharga yang menjadi instrument investasi. Sukuk menurut sejarahnya pernah dikenal pada abad ke 7 zaman khalifah Umayyah. Ketika itu disebut Sukuk al-Badai yaitu semacam kupon yang menandankan bahwa kita memiliki barang yang disimpan di suatu gudang. Menurut Imam Malik dalam bukunya al-Muwatta Sukuk al-badai ini bisa diperjual belikan sebelum jatuh tempo5. Sukuk ini dapat disebut seperti Obligasi tetapi bukan mengandung bunga tetapi didesain sedemikian rupa

${ }^{5}$ Rafe Haneef, International Islamic Financial market, Grand Hyatt Jakarta, International Conference oIslamic Banking, Capital and Financial Market \& International Workshop on Sukuk, 12 September 2006. 
sehingga menjadi surat berharga yang sesuai dengan syariah. Sukuk ini bisa disusun dalam bentuk skim murabahah, mudharabah, musyarakah, ijarah dan salam atau campuran antara dua atau lebih skim syariah. Bahrain adalah negara pertama yang mengeluarkan sukuk pada September 2001 diikuti oleh Malaysia pada juni 2002. Di Indonesia yang pertama mengeluarkan sukuk korporasi adalah PT Indosat. Sukuk ini sangat penting untuk menjembatani kebutuhan surat berharga yang bisa dijadikan instrument untuk memenuhi likuiditas seandainya lembaga memerlukan.

Di Indonesia skim yang populer adalah skim ijarah dan murabahah. Dalam skim Ijarah investor membeli barang atau property kemudian disewakan kembali kepada pengguna dana. Sedangkan dalam skim murabahah barang dibeli kemudian dijual kepada pembeli dan dapat diangsur atau dibayar pada saat jatuh tempo yang disepakati dalam akad.

Total pasar instrument ekuitas dunia mencapai sekitar US\$ 39 triltion sedangkan potensi surat berharga syariah sekitar 24\% atau US\$ 9,36 trilyun. Sedangkan pasar keuangan Islam ditaksir US\$ 400 milyar dan Pasar Uang Islam sekitar US\$3-50 milyar. Pertumbuhannya cukup tinggi yaitu sekitar 15\%. Sudah ada 300 lembaga keuangan Islam di dunia yang berada di lebih 75 negara baik muslim maupun non muslim. Sejauh ini sudah ada 100 jenis equity fund dengan nilai US\$ 5 milyar. Sedangkan pertumbuhan Pasar Modal Islam per tahun adalah 15-20\%. Menurut taksiran pada tahun 2004 sukuk hanya US 6,7 milyar tetapi pada tahun 2007 sudah naik hamper 35\% menjadi US 9. milyar. Pada taun 2007 dan 2008 ditaksir masing masing menjadi US\$ 25 milyuar dan US 50 milyar, suatu kenaikan yang sangat substansial ${ }^{6}$. Menurut catatan Bank Indonesia (2008) jumlah Sukuk di Indonesia per 31 Desember 2007 telah mencapai Rp. 3,0974 trilyun dengan jumlah emiten 19 dan dua dari sukuk itu dengan nominal Rp 235 milyar telah selesai dan dilunasi (lihat Tabel 1 dan Tabel 2). Pemerintah merencanakan akan mengeluarkan Sukuk atau SBSN sekitar 15 trilyun pada tahun 2008 dan juga direncanakan akan mengeluarkan SUKUK ritel yang akan dijual pada February $2009^{7}$. Namun jumlah ini masih sangat kecil dibandingkan dengan potensi dan kebutuhan dana pemerintah.

Tabel 1: Daftar Sukuk dan Emiten Pasar Modal Syariah Indonesia Desember 2007

\begin{tabular}{|l|l|l|c|c|c|c|}
\hline No & \multicolumn{1}{|c|}{ Nama } & \multicolumn{1}{|c|}{ Emiten } & $\begin{array}{c}\text { Rp } \\
\text { (milyar) }\end{array}$ & $\begin{array}{c}\text { Tanggal } \\
\text { issue }\end{array}$ & Pelunasan & Akad/Skim \\
\hline 1 & $\begin{array}{l}\text { Berlian Lajur } \\
\text { Tanker Syariah } \\
\text { Mudharabah Th } \\
2003\end{array}$ & $\begin{array}{l}\text { PT. Berlina } \\
\text { Laju Tanker } \\
\text { Tbk }\end{array}$ & 60.00 & 5 -Dec-03 & 28-May-08 & Mudharabah \\
\hline
\end{tabular}

${ }^{6}$ Alvi, International Islamic Financial Market, Grand Hyatt Jakarta, International Conference on Islamic Banking, Capital and Financial Market \& International Workshop on Sukuk, 12 September 2006.

${ }^{7}$ Kompas, Sukuk itel Dijual Februari 2009, Kompas 25 November 2008 hal. 19. 


\begin{tabular}{|c|c|c|c|c|c|c|}
\hline No & Nama & Emiten & $\begin{array}{c}\text { Rp } \\
\text { (milyar) }\end{array}$ & $\begin{array}{c}\text { Tanggal } \\
\text { issue }\end{array}$ & Pelunasan & Akad/Skim \\
\hline 2 & $\begin{array}{l}\text { Bank Bukopin } \\
\text { Syariah } \\
\text { Mudharabah Th } \\
2003 \\
\end{array}$ & $\begin{array}{l}\text { PT. Bank } \\
\text { Bukopin }\end{array}$ & 45.00 & 30-Jun-03 & 10-Jul-08 & Mudharabah \\
\hline 3 & $\begin{array}{l}\text { Bank Muamalat } \\
\text { Syariah } \\
\text { Mudharabah Th. } \\
2003\end{array}$ & $\begin{array}{l}\text { PT. Bank } \\
\text { Muamalat } \\
\text { Indonesia }\end{array}$ & 200.00 & 30-Jun-03 & 15-Jul-10 & Mudharabah \\
\hline 4 & $\begin{array}{l}\text { Bank Syariah } \\
\text { Mandiri Syariah } \\
\text { Mudharabah Th. } \\
2003\end{array}$ & $\begin{array}{l}\text { PT. Bank } \\
\text { Syariah Mandiri }\end{array}$ & 200.00 & $22-\mathrm{Oct}-03$ & 31-Okt-08 & Mudharabah \\
\hline 5 & $\begin{array}{l}\text { PTPM VII Syariah } \\
\text { Mudharabah Th. } \\
2004\end{array}$ & $\begin{array}{l}\text { PT. Perkebunan } \\
\text { Nusantara VII } \\
\text { Tbk }\end{array}$ & 75.00 & 18-Mar-04 & 26-Mar-09 & Mudharabah \\
\hline 6 & $\begin{array}{l}\text { Matahari Putra } \\
\text { Prima Syariah Ijarah } \\
\text { I Th. } 2004\end{array}$ & $\begin{array}{l}\text { PT. Matahari } \\
\text { Putra Prima } \\
\text { Tbk }\end{array}$ & 150.00 & 28-Apr-04 & 11-May-09 & Ijarah \\
\hline 7 & $\begin{array}{l}\text { Sona Topas Tourism } \\
\text { Industry Syariah } \\
\text { Ijarah I Th. } 2004\end{array}$ & PT. Sona Topas & 150.00 & 17-Jun-04 & 28-Jun-09 & Ijarah \\
\hline 8 & $\begin{array}{l}\text { Citra Sari Makmur } \\
\text { I Syariah Ijarah I } \\
\text { Th. } 2004 \\
\end{array}$ & $\begin{array}{l}\text { PT. Citra Sari } \\
\text { Makmur }\end{array}$ & 100.00 & 29-Jun-04 & 9-Jul-09 & Ijarah \\
\hline 9 & $\begin{array}{l}\text { Indorent I Syariah } \\
\text { Ijarah I Th. } 2004\end{array}$ & $\begin{array}{l}\text { PT. CSM } \\
\text { Corporatama }\end{array}$ & 100.00 & 1-Nov-04 & 11-Nov-08 & Ijarah \\
\hline 10 & $\begin{array}{l}\text { Berlina I Syariah } \\
\text { Ijarah I Th. } 2004\end{array}$ & PT. Berlian Tbk & 85.00 & 2-Dec-04 & 15-Dec-09 & Ijarah \\
\hline 11 & $\begin{array}{l}\text { HITS I Syariah } \\
\text { Ijarah I Th. } 2004\end{array}$ & $\begin{array}{l}\text { PT. Humpuss } \\
\text { Intermoda Tbk }\end{array}$ & 122.00 & 13-Dec-04 & 17-Dec-09 & Ijarah \\
\hline 12 & $\begin{array}{l}\text { Apesindo Pratama } \\
\text { Duta I Syariah } \\
\text { Syariah Ijarah I Th } \\
2005\end{array}$ & $\begin{array}{l}\text { PT. Apesindo } \\
\text { Pratama Duta }\end{array}$ & 240.00 & 30-Mar-05 & 30-Mar-10 & Ijarah \\
\hline 13 & $\begin{array}{l}\text { Indosat Syariah } \\
\text { Ijarah I Th. } 2005\end{array}$ & $\begin{array}{l}\text { PT. Indosat } \\
\text { Tbk }\end{array}$ & 285.00 & 13-Jun-05 & 21-Jun-11 & Ijarah \\
\hline 14 & $\begin{array}{l}\text { Ricky Putra } \\
\text { Globalindo I } \\
\text { Syariah Ijarah I Th. } \\
2005\end{array}$ & $\begin{array}{l}\text { PT. Ricky Putra } \\
\text { Globalindo Tbk }\end{array}$ & 60.40 & 7-Jul-05 & 12-Jun-10 & Ijarah \\
\hline 15 & $\begin{array}{l}\text { Syariah Ijarah PLN } \\
\text { I Tahun } 2006\end{array}$ & $\begin{array}{l}\text { PT. Perusahaan } \\
\text { Listrik Negara }\end{array}$ & 200.00 & 12-Jun-06 & 21-Jun-16 & Ijarah \\
\hline 16 & $\begin{array}{l}\text { Sukuk Syariah } \\
\text { Ijarah Indosat II Th } \\
2007\end{array}$ & $\begin{array}{l}\text { PT. Indosat } \\
\text { Tbk }\end{array}$ & 400.00 & 29-May-07 & 29-May-14 & Ijarah \\
\hline 17 & $\begin{array}{l}\text { Sukuk Syariah } \\
\text { Ijarah Berlian Laju } \\
\text { Tanker Th. } 2007 \\
\end{array}$ & $\begin{array}{l}\text { PT. Berlian } \\
\text { Laju Tanker } \\
\text { Tbk }\end{array}$ & 200.00 & 5-Jul-07 & 5-Jul-12 & Ijarah \\
\hline 18 & $\begin{array}{l}\text { Sukuk Mudharabah } \\
\text { Adhi I Th. } 2007\end{array}$ & $\begin{array}{l}\text { PT. Adhi Karya } \\
\text { (Persero) Tbk }\end{array}$ & 125.00 & 6-Jul-07 & 6-Jul-13 & Mudharabah \\
\hline
\end{tabular}


Sofyan Syafri Harahap: Sukuk sebagai Instrument Pendanaan ...

\begin{tabular}{|l|l|l|c|c|c|l|}
\hline No & \multicolumn{1}{|c|}{ Nama } & \multicolumn{1}{|c|}{ Emiten } & $\begin{array}{c}\text { Rp } \\
\text { (milyar) }\end{array}$ & $\begin{array}{c}\text { Tanggal } \\
\text { issue }\end{array}$ & Pelunasan & Akad/Skim \\
\hline 19 & $\begin{array}{l}\text { Sukuk Ijarah PLN } \\
\text { II Th 2007 }\end{array}$ & $\begin{array}{l}\text { PT. Perusahaan } \\
\text { Listrik Negara }\end{array}$ & 300.00 & $10-J u l-07$ & 10 -Jul-17 & Ijarah \\
\hline
\end{tabular}

Sumber: Laporan Perkembangan Perbankan Syariab Tabun 2007

Table 2: Sukuk yang Telah Dilunasi (Paid/Buy Back)

\begin{tabular}{|l|l|l|r|l|l|l|}
\hline 1 & Ciliandra Perkasa & $\begin{array}{l}\text { PT. Ciliandra } \\
\text { Perkasa }\end{array}$ & 175.00 & 18-Sep-03 & & Mudharabah \\
\hline 2 & $\begin{array}{l}\text { OS Mudharabah } \\
\text { Indosat Th 2002 }\end{array}$ & $\begin{array}{l}\text { PT. Indosat } \\
\text { Tbk }\end{array}$ & 60.00 & 30-Oct-02 & 6-Nov-07 & Mudharabah \\
\hline
\end{tabular}

Sumber: Laporan Perkembangan Perbankan Syariab Tabun 2007

Angka diatas menunjukkan bahwa potensi sukuk sangat besar, kinerjanya cukup bagus serta instrument ini sangat dibutuhkan oleh pasar terutama untuk memenuhi kebutuhan likuiditasnya, serta menambah portofolio investasi serta mendistribusikan berbagai risiko keuangan. Untuk memperlancar proses sukuk diterima pasar maka banyak Negara seperti UK khususnya London, Singapure dan Hongkong telah melakukan berbagai upaya agar produk atau skim keuangan syariah ini bisa masuk dalam pasar keuangan mereka. Malaysia termasuk berhasil, mereka telah mampu menyerap $80 \%$ pasar sukuk. Ini yang membuat Singapure, Hongkong dan London ingin memanfatkan peluang itu. Bagaimana dengan di Indonesia? Dibandingkan dengan Malaysia, Singapure, Hong Kong dan London, kita jauh ketinggalan dan ada perbaikan namun tampaknya keseriusan pemerintah bukan karena kebutuhan tetapi karena desakan rakyat saja. Hal ini terbukti dari saran Indonesian Paper di pertemuan G-20 yang meminta IMF dapat menyediakan dana pinjaman negara "emerging market" untuk mengatasi dampak krisis global. Bahkan menurut Media Indoensia 25 November 2009 pada tahun 2009 Indonesia akan melakukan pinjaman LN untuk menopang APBNnya yang sebelumnya sudah dilunasi dan Presiden sudah berjanji tidak akan memakai model IMF lagi.

Khusus di Indonesia ada beberapa kendala yang perlu diatasi oleh pelaku pasar dan juga regulator. Beberapa kendala itu adalah: Pertama: aspek legalitas. Walaupun Indonesia sudah memiliki UU SUKUK atau yang dikenal dengan Surat Berharga Syariah Negara (SBSN) yang disetujui DPR pada tahun 2008 namun UU ini tidak bisa sendirian kendatipun peraturan dan petunjuk teknisnya sudah ada. Aspek hokum diluar sukuk ini masih banyak yang kadang tidak mendukung Sukuk misalnya mengenai kelengakapan surat asset Negara dan keakuratan catat akuntansinya. Hal ini masih harus menjadi tugas pemerintah. Kedua: Kemauan Politik. Pengembangan industri keuangan syariah di Indonesia di dorong oleh ummat Islam dan satu satunya lembaga Negara yang paling aktif hanya Bank Indonesia. Sedangkan untuk menjadikan sukuk ini sebagai instrument yang meluas maka diperlukan peranan pemerintah, misalnya Departemen Keuangan, Menteri Negara BUMN dan lembaga lain seperti Departemen Hukum dan 
HAM, Departemen Pendidikan Nasional serta Pemda. Tanpa dukungan politik yang serius maka pertumbuhan sukuk ini akan bisa lamban. Ketiga: Aspek Perpajakan. sejauh ini belum tuntas bagaimana sikap Ditjen Pajak terhadap double taxation atas skim pembiayaan murabahah atau jual beli. Tampaknya Ditjen Pajak belum mengakui bahwa skim jual beli dalam industri keuangan adlaah skim pembiayaan bukan skim jual beli yang sesungguhnya. Sehingga Ditjen Pajak terus menagih PPN atas pembelian barang yang dilakukan oleh Bank. Sehingga harga pokok dan biaya nasabah bisa naik diatas $11 \%$ dari harga normal. Tanpa upaya pemerintah secara menyeluruh untuk mengatasi kedala diatas maka saya khawatir peran sukuk yang demikina penting dan potensial untuk menjadi pendanaan pemerintah dan korporasi tidak akan memberikan dampak positif bagi pembangunan ekonomi kita.

\section{Penutup}

Dengan semakin langkanya likuiditas untuk pembangunan dan kegiatan perusahaan yang berasal adri USA, Eropa dan Jepang maka sudah saatnya pemerintah melirik sumber pendanaan yang berasal dari sumber lain dan negara lain. Krisis keuangan global telah menimbulkan kekhawatiran masyarakat dunia terhadap keberlanjutan (sustainability) dari dana dan ekonomi dunia dalam system kapitalisme. Krisis global telah membuktikan bahwa dananya menjadi hangus dan tidak kembali. Wajar jika popularitas portofolio keuangan syariah semakin diminati ${ }^{8}$. Sukuk adalah salah satu instrumen pasar uang yang bisa dibuat jangka panjang, menengah dan pendek. Apalagi untuk kebutuhan pendanaan pembangunan maka skim SUKUK negara ini sangat bsia digunakan. Sejauh ini negara negara lain telah berhasil menarik dana dalam skim suku ini dan potensinya sangat besar. Oleh karenanya maka sudah saatnya Pemerintah Pusat atau Pemda ataupun swasta untuk menggunakan skim sukuk ini. Namun kepada pemerintah diharapkan bisa menyempurkan semua perangkat keras dan lunak untuk menciptakan produk ini bisa lebih menarik dan tidak menghadapi berbagai ekndala seperti diuraikan diatas. Sukuk diharapkan akan dapat menutupi kebutuhan dana pembanguan yang saat ini langka dan lebih baik daripada menggunakan skim pendanaan IMF yang sudah terbukti menyengsarakan rakyat dan mengurangi kemandirian dan kemerdekaan bangsa.

\section{DAFTAR PUSTAKA}

Abdul Ghafour (2008), "Islamic Finance panacea for global crisis: Chapra", wawancara dengan Umer Chapra, Arab News.

Ariyanti, Ratna dan Tri D Pamenan (2008), G-20 perkuat regulasi sektor

${ }^{8}$ Balfour "Islamic Finance May Be On to Something". BusinessWeek, November 24, 2008 hal. 38. 
Sofyan Syafri Harahap: Sukuk sebagai Instrument Pendanaan ...

Keuangan, Bisnis Indonesia. Selasa 11 November 2008.

Bank Indonesia (2008), Laporan Perkembangan Perbankan Syariah Tahun 2007. Jakarta: Bank Indonesia

Fredrick Balfour (2008), "Islamic Finance May Be On to Something". Business Week, November 24, 2008.

F. Fukuyama (1992), The End of History and the Last Man. USA: Perennial, Harper Collins Publisher.

Ijlal A Alvi (2006), International Islamic Financial Market, Grand Hyatt Jakarta, International Conference on Islamic Banking, Capital and Financial Market \& International Workshop on Sukuk, 12 September 2006.

Kompas (2008), Sukuk Ritel Dijual Februari 2009, Kompas 25 November 2008.

LeVine, Steve (2008), The IMF is Back, Kinder and Gentler, BusinessWeek, November 10, 2008.

Rafe Haneef (2006), International Islamic Financial Market, Grand Hyatt Jakarta, International Conference on Islamic Banking, Capital and Financial Market \& International Workshop on Sukuk, 12 September 2006.

Raja Hendrik Napitupulu (2008), "2009 jumlah orang miskin jadi 43 Juta jiwa, Penduduk miskin melonjak", Investor Daily, Senin 24 November, 2008.

Sofyan S Harahap (2008), "Ekonomi Syriah Yang Sabar Menunggu", Republika, 29 September 2008. -- (2008a) "Ekonomi Syariah, Bretton Woods, KTT ASEM dan AS". Republika, Senin 3 November 2008. 